\title{
Clonal origin of non-medullary thyroid tumours assessed by non-random $\mathrm{X}$-chromosome inactivation
}

Sónia Moniz, Ana L Catarino ${ }^{1}$, Ana R Marques, Branca Cavaco, Luís Sobrinho and Valeriano Leite

Centro de Investigação de Patobiologia Molecular (CIPM) and ${ }^{1}$ Departamento de Patologia Morfológica, Instituto Português de Oncologia de Francisco Gentil, Rua Professor Lima Basto, 1099-023 Lisboa, Portugal

(Correspondence should be addressed to Sónia Moniz; Email: sonia.moniz@clix.pt)

\begin{abstract}
Objective: X-chromosome inactivation analysis was performed in order to assess the clonal origin of non-medullary thyroid tumours and to distinguish between multicentricity and multifocality in multiple papillary thyroid carcinoma (PTC).

Methods: One hundred and thirteen tumour samples from 31 patients with isolated PTC, 16 patients with multinodular PTC, 14 patients with follicular thyroid adenoma (FTA) and 15 patients with follicular thyroid carcinoma (FTC) were collected. The corresponding normal thyroid tissues were analysed, and in 14 cases, tumour-surrounding tissue was also studied. Genomic DNA was digested with HpaII and HhaI previous to PCR amplification of the polymorphic CAG repeat, on exon 1 of the human androgen receptor gene (HUMARA). PCR products were analysed by denaturing gel electrophoresis, silver staining and densitometric analysis. PCR products were also used to determine the number of CAG repeats of patients with isolated PTC, FTA, FTC and of 41 healthy volunteers. Results: Heterozygosity for the HUMARA polymorphism was found in 64/76 (84\%) cases. Lyonization of the thyroid was observed in 15/76 (20\%) cases, which were excluded from clonal analysis. Except for two cases of isolated PTC, all tumour samples studied presented monoclonal X-inactivation patterns, while normal thyroid tissue was polyclonal. Monoclonal patterns were also found in 4/14 tumour-surrounding tissues. No difference was found in the length of CAG alleles between patients and controls. Of eight informative cases of multinodular PTC, three showed evidence of multicentricity and five revealed patterns consistent with multifocality.

Conclusions: Both isolated and multinodular PTC as well as FTA and FTC are of monoclonal origin. Our results also suggest that approximately one-third of multiple PTC have an independent origin for the different nodules (multicentricity). Monoclonality was also found in tissues surrounding some PTC nodules. No association was found between the length of CAG alleles and thyroid malignancies.
\end{abstract}

European Journal of Endocrinology 146 27-33

\section{Introduction}

Clonal analysis of neoplastic lesions can offer some insight on the mechanisms involved in tumour formation and disease progression. This analysis has been successfully used to discriminate between multicentricity and multifocality in breast carcinoma (1), to distinguish between primary and secondary carcinoma in the breast (2), and to identify the origin of late recurrent ovary carcinoma (3). These studies have also helped to clarify the origin of macroscopically and microscopically heterogeneous nodules present in many multinodular goitres (4).

The few available studies on the clonal origin of thyroid tumours have produced conflicting results. In 1976, Fialkow (5) used the protein polymorphism of the glucose-6-phosphate-dehydrogenase (G6PD) enzyme, to study five cases of thyroid tumours and found a monoclonal pattern in all of them. In 1990, Namba et al. (6) studied the clonality of several thyroid tumours with the hypoxanthine phosphoribosyl transferase (HPRT) and phosphoglycerate kinase (PGK) probes by Southern blot analysis. They concluded that $6 / 6$ follicular thyroid adenomas (FTA), 2/2 follicular thyroid carcinomas (FTC), 1/1 anaplastic carcinoma and 1/3 papillary thyroid carcinomas (PTC) were monoclonal, while two out of three PTC had a polyclonal pattern. In 1992, Fey et al. (7) studied two cases of thyroid carcinomas, the histological type of which was not specified, and considered them to be monoclonal. In 1998, Kim et al. (8) found 8/8 PTC, 2/2 FTA and 10/13 follicular nodules from nodular goitres, to be of monoclonal origin. There is only one study in which the clonality of medullary thyroid carcinomas (MTC) was evaluated. In this study, six cases of sporadic MTC and five cases of multiple endocrine neoplasia (MEN) syndrome were 
analysed. The authors found all the cases with MEN syndrome and all but one of the sporadic MTC cases to be of polyclonal origin (9).

All these studies were performed using DNA from fresh thyroid tissues, which often contain cells of polyclonal origin such as stromal cells, fibroblasts or peripheral blood cells. These form a polyclonal background that may blur the distinction between mono- and polyclonal patterns. The analysis of paraffin-embedded thyroid tissues might prevent contamination of tumour samples with other cell types since the areas of interest may be selected microscopically.

The aim of this work was to elucidate the clonal origin of thyroid tumours of follicular origin and to provide a means to discriminate between multicentricity and multifocality in the cases presenting a multinodular form of PTC. For this purpose we performed X-chromosome inactivation analysis, by means of a PCR-based methodology for the polymorphic CAG repeat locus, on exon 1 of the human androgen receptor gene (HUMARA) (10), using DNA samples extracted from fresh and paraffin-embedded tissues.

\section{Materials and methods}

\section{Samples}

Tumour samples from 31 females with isolated PTC, 16 females with multinodular PTC, 14 females with FTA and 15 females with FTC were collected. Thirty-nine tumour samples from patients with multinodular PTC were analysed. The 1988 WHO histological classification was followed.

Tumour samples from patients with FTA and from 12 cases with isolated PTC were collected only from tissue surgically removed and snap-frozen in liquid nitrogen. Tumour samples from the remaining cases of isolated PTC were obtained from paraffin-embedded tissue (six cases) or from tissues preserved by both methods (13 cases). All samples from patients with multinodular PTC and from patients with FTC were obtained from paraffin-embedded tissues.

For each case, normal thyroid tissue, usually from the contralateral lobe, was also studied and, for one multinodular and 13 isolated PTC cases, a parallel analysis was also carried out for histologically normal tissue surrounding the tumour.

Tumour samples frozen in liquid nitrogen had an average diameter of $0.5 \mathrm{~cm}$. Five to seven $50 \mu \mathrm{m}$ cuts were made of each biological sample from paraffinembedded tissues, the diameter of which varied from 0.3 to $2 \mathrm{~cm}$.

DNA was obtained by proteinase $\mathrm{K}$ digestion in a solution containing $0.2 \mathrm{mg} / \mathrm{ml}$ Proteinase $\mathrm{K}$ (Promega, Madison, WI, USA), $1 \mathrm{mmol} / \mathrm{l} \mathrm{Na}_{2}$ EDTA, $50 \mathrm{mmol} / \mathrm{l}$ Tris-HCl pH 8.5, 0.5\% (v/v) Tween20, incubated overnight at $56^{\circ} \mathrm{C}$. DNA purification involved a standard procedure of phenol:chloroform extraction and ethanol precipitation (11).

\section{$X$-inactivation analysis}

The assessment of X-chromosome inactivation patterns involved a digestion of DNA samples with methylationsensitive restriction endonucleases HpaII and HhaI. Although several authors followed a similar strategy for the analysis of X-chromosome inactivation while using only HpaII, we observed an improved restriction efficiency when HpaII and HhaI where used simultaneously, compared with HpaII or HhaI alone (Fig. 1).

In order to evaluate the efficiency of the restriction reactions, two control samples were included in each assay: DNA obtained from lymphocytes of a male healthy donor, since the only male X-chromosome is functionally active and therefore the restriction sites for HpaII and HhaI are both unmethylated (10), and DNA obtained from a female thyroid tissue whose pattern of X-inactivation was clearly monoclonal.

Aliquots of about $1 \mu \mathrm{g}$ of purified DNA were then incubated overnight, at $37^{\circ} \mathrm{C}$, with $20 \mathrm{U}$ of each restriction enzyme HpaII and HhaI (New England Biolabs, Inc., Beverly, MA, USA), using the digestion buffer supplied for HhaI $(50 \mathrm{mmol} / \mathrm{l}$ potassium acetate, $20 \mathrm{mmol} / \mathrm{l}$ Tris acetate, $10 \mathrm{mmol} / \mathrm{l}$ magnesium acetate, $10 \mathrm{mmol} / \mathrm{l} \mathrm{DTT}, \mathrm{pH} 7.9$ at $25^{\circ} \mathrm{C}$ ) supplemented with $100 \mu \mathrm{g} / \mathrm{ml} \mathrm{BSA}$, in a total reaction volume of $40 \mu \mathrm{l}$. The corresponding undigested DNA was incubated in similar conditions except for the addition of the restriction enzymes. The reactions were terminated by heat inactivation at $95^{\circ} \mathrm{C}$ for $10 \mathrm{~min}$.

Eight microlitres of (HpaII+HhaI)-digested or undigested DNA were then used in a $40 \mu \mathrm{l}$ PCR reaction containing $0.2 \mu \mathrm{mol} / \mathrm{l}$ of each oligonucleotide primer (Amersham Pharmacia Biotech, Uppsala, Sweden), $200 \mu \mathrm{mol} / \mathrm{l}$ dNTPs (Amersham Pharmacia Biotech), 0.06 U Taq DNA polymerase (Gibco BRL, Life Technologies, Inc., Gaithersburg, MD, USA), $3 \mathrm{mmol} / \mathrm{l} \mathrm{MgCl}_{2}$, $20 \mathrm{mmol} / \mathrm{l}$ Tris $-\mathrm{HCl}$ (pH 8.4), $50 \mathrm{mmol} / \mathrm{l} \mathrm{KCl}$. The oligonucleotide primers (forward and reverse) used in this

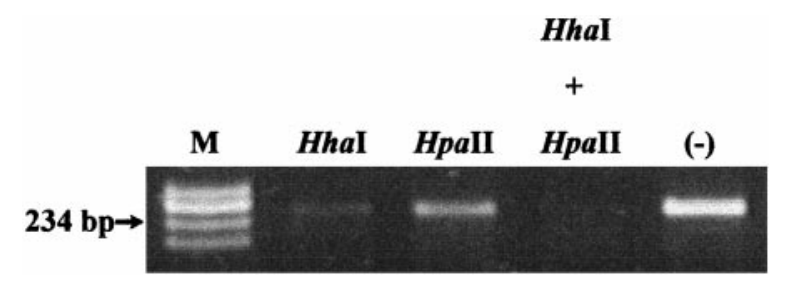

Figure 1 Optimization of restriction conditions using enzymes Hpall and $\mathrm{Hhal}$, to obtain complete male DNA digestion. The best conditions are identified by the complete disappearance of the band corresponding to the expected PCR product and were achieved when both enzymes were used simultaneously. M, molecular weight marker; Hpall+Hhal, DNA incubated with Hpall+Hhal; $(-)$, DNA incubated without Hpall+Hhal. 
assay (12) originate a PCR product of about $230 \mathrm{bp}$ comprising the CAG repeat and the restriction sites for HpaII and HhaI. PCR reactions were performed in a UNO II thermocycler (Biometra, Germany) for 40 cycles of amplification, each comprising $1 \mathrm{~min}$ at $95^{\circ} \mathrm{C}, 1 \mathrm{~min}$ at $56^{\circ} \mathrm{C}$ and $1 \mathrm{~min}$ at $72{ }^{\circ} \mathrm{C}$, after an initial 5-min denaturation step at $95^{\circ} \mathrm{C}$, and with a final extension step of $10 \mathrm{~min}$ at $72^{\circ} \mathrm{C}$.

\section{Gel electrophoresis and densitometric analysis}

Ten microlitres of each PCR product were mixed with an identical volume of loading buffer $(98 \%(\mathrm{v} / \mathrm{v})$ formamide, $20 \mathrm{mmol} / \mathrm{l} \mathrm{NaOH}, \quad 0.1 \%(\mathrm{w} / \mathrm{v})$ bromophenol blue, $0.1 \%(\mathrm{w} / \mathrm{v})$ xylene cyanol) and $14 \mu \mathrm{l}$ of this mixture was loaded on a denaturing 8\% 29:1 acrylamide/ bis-acrylamide gel ( $8 \mathrm{~mol} / \mathrm{l}$ urea, $20 \%$ (v/v) formamide, $1 \times$ TBE). Electrophoresis was performed at $60 \mathrm{~W}$ for $6 \mathrm{~h}$. X-chromosome inactivation patterns were then visualized using a silver staining procedure adapted from Bassam et al. (13). The gel was dried, digitalized and a densitometric analysis of the band intensities was performed using the ONE-Dscan software (Scanalytics, A Division of CSPI, USA).

The relationship between the intensities of the bands generated by the PCR products, from digested and undigested DNA, allows the determination of an allelic cleavage ratio (ACR), the parameter on which our assessment of clonality for a given tissue is based. For the ACR determination, the ratio of the intensities for both alleles was calculated and the ratio for the undigested DNA was divided by the corresponding ratio for (HpaII+ HhaI)-digested DNA. When necessary, the resulting number was inverted to give a value greater than 1 . A polyclonal tissue has in theory $50 \%$ of cells with each $\mathrm{X}$-chromosome inactivated, which corresponds to an ACR value of 1. Conversely, in a monoclonal tissue all cells contain the same X-chromosome inactivated and, after DNA digestion with HpaII and HhaI, only one fragment from either the maternal or paternal allele should be amplified. However, contamination with DNA from non-tumour polyclonal cells is frequent, resulting in a background amplification of the active allele. Thus, in line with Krohn et al. (14), the tissue was considered to be of polyclonal origin when the determined ACR value was below 2 and a monoclonal origin was suggested for tissues with ACR values above 2 .

\section{Determination of the length of CAG repeats in the HUMARA alleles}

PCR products from tumour samples of four patients, heterozygous for the CAG repeat polymorphism, were sequenced. In brief, PCR products were firstly purified by electrophoresis on a $1.5 \%$ agarose gel, the desired bands were extracted with the use of Qiaquick Gel Extraction Kit (Qiagen GmbH, Hilden, Germany) and cloned using the pGEM-TEasy Vector System I
(Promega). The plasmid DNA was isolated using the Qiaprep Spin Miniprep Kit (Qiagen $\mathrm{GmbH}$ ), and sequenced with the fmol DNA Cycle Sequencing System (Promega). Seven different CAG alleles were then used as molecular weight markers and the number of CAG repeats was determined for cases of isolated and multinodular PTC, FTA, FTC and in 41 healthy volunteers.

Informed consent was obtained from the subjects in this study.

\section{Statistical analysis}

Results are shown as means \pm s.D.s. The differences in homozygosity frequency among patients with different tumour types were analysed by chi-square with Yates' correction; $P<0.05$ was considered significant.

\section{Results}

Of the 76 cases included in this study, 64 (84\%) were informative for the $(\mathrm{CAG})_{n}$ polymorphism in exon 1 of the HUMARA gene. Although Allen et al. (10) reported a $>90 \%$ percentage of heterozygosity with the HUMARA polymorphism in the general population, a difference in the frequency of homozygosity between the several groups studied was observed. Homozygosity was found in $31 \%(5 / 16)$ of the multinodular PTC and in $27 \%(4 / 15)$ of the cases with FTC, but only in $7 \%$ of both isolated PTC and FTA (2/31 and $1 / 14$ cases respectively). Statistical analysis showed that these differences were not significant.

In $15(20 \%)$ cases (three multinodular PTC, six isolated PTC, three FTA and three FTC), we observed a non-random X-chromosome inactivation in both neoplastic and normal thyroid tissues (lyonization) and these cases were not considered for the assessment of clonality. Of these cases, 12 (two multinodular PTC, six isolated PTC, two follicular adenomas and two follicular carcinomas) had the largest HUMARA allele in the inactive $\mathrm{X}$-chromosome.

Except for cases 47 and 51 (Table 1), all tumour samples from isolated PTC had non-random X-inactivation, which suggests a monoclonal origin of these neoplasias. The two cases with random X-inactivation were strongly contaminated with lymphocytes, due to thyroiditis, which may explain the polyclonal pattern observed in these tumours. All cases of FTA and FTC presented non-random X-chromosome inactivation patterns (Table 2). Taken together, these results point to a monoclonal origin of thyroid tumours of follicular origin.

The average ACR value of normal thyroid tissues (excluding cases of homozygosity and lyonization) was $1.35 \pm 0.16$ (mean \pm s.D.). This value is very similar to $1.31 \pm 0.26$ (mean \pm s.D.), reported by Krohn et al. (14). Thus, the use of an ACR value above 2 as a monoclonality index was justified since it is more than 2 S.D. 
Table 1 Results of clonal analysis of tumour samples from isolated PTC.

\begin{tabular}{|c|c|c|c|c|c|}
\hline \multirow[b]{2}{*}{ Case } & \multicolumn{2}{|c|}{ ACR values } & \multirow{2}{*}{$\begin{array}{c}\text { X-inactivation } \\
\text { pattern }\end{array}$} & \multirow{2}{*}{$\begin{array}{l}\text { Inactive } \\
\text { allele }\end{array}$} & \multirow[b]{2}{*}{ Clonal origin } \\
\hline & Fresh & Paraffin & & & \\
\hline 6 & 7.6 & 3.3 & NR & L & Monoclonal \\
\hline 8 & 33.2 & 5.7 & NR & L & Monoclonal \\
\hline 9 & 24.9 & 3.1 & NR & $\mathrm{S}$ & Monoclonal \\
\hline 10 & - & 4.2 & NR & $\mathrm{L}$ & Monoclonal \\
\hline \multirow[t]{2}{*}{11} & - & 7.7 & NR & $\mathrm{L}$ & Monoclonal \\
\hline & & $4.6^{*}$ & NR & $\bar{L}$ & \\
\hline 14 & 2.9 & 2.2 & NR & L & Monoclonal \\
\hline 15 & - & 2.9 & NR & $\bar{S}$ & Monoclonal \\
\hline 18 & - & 2.8 & NR & L & Monoclonal \\
\hline 32 & - & 2.2 & NR & $\mathrm{S}$ & Monoclonal \\
\hline 35 & 4.5 & 4.2 & NR & L & Monoclonal \\
\hline 36 & 10.4 & 6.1 & NR & L & Monoclonal \\
\hline 39 & 10.3 & 2.8 & NR & L & Monoclonal \\
\hline 42 & 12.3 & 2.2 & NR & $\mathrm{S}$ & Monoclonal \\
\hline 43 & 2.5 & 6.3 & NR & $\mathrm{S}$ & Monoclonal \\
\hline 45 & 2.6 & - & NR & $\mathrm{S}$ & Monoclonal \\
\hline 47 & 1.3 & 1.4 & $\mathrm{R}$ & - & Polyclonal \\
\hline 48 & 5.4 & - & NR & $\mathrm{S}$ & Monoclonal \\
\hline 50 & 25.7 & - & NR & $\mathrm{L}$ & Monoclonal \\
\hline 51 & 1.4 & 1.5 & $\mathrm{R}$ & - & Polyclonal \\
\hline 52 & 16.4 & - & NR & L & Monoclonal \\
\hline 55 & 4.1 & - & NR & L & Monoclonal \\
\hline 56 & 2.6 & - & NR & $\mathrm{L}$ & Monoclonal \\
\hline 57 & 3.64 & - & NR & S & Monoclonal \\
\hline
\end{tabular}

NR, non-random X-inactivation; R, random X-inactivation; L, larger allele inactive; S, shorter allele inactive; *lymph node metastasis.

above the average index found for polyclonal thyroid tissue. For all tumour samples with non-random $\mathrm{X}$-chromosome inactivation, the highest and lowest ACR values calculated were 42.2 and 2.0 respectively (Tables 1-3).

Table 2 Results of clonal analysis of tumour samples from follicular adenomas and carcinomas.

\begin{tabular}{ccccc}
\hline Case & $\begin{array}{c}\text { ACR } \\
\text { values }\end{array}$ & $\begin{array}{c}\text { X-inactivation } \\
\text { pattern }\end{array}$ & $\begin{array}{c}\text { Inactive } \\
\text { allele }\end{array}$ & $\begin{array}{c}\text { Clonal } \\
\text { origin }\end{array}$ \\
\hline $\begin{array}{c}\text { Follicular adenomas } \\
4\end{array}$ & 5.7 & NR & L & Monoclonal \\
5 & 10.2 & NR & S & Monoclonal \\
7 & 15.2 & NR & L & Monoclonal \\
66 & 18.0 & NR & L & Monoclonal \\
67 & 2.9 & NR & L & Monoclonal \\
68 & 6.7 & NR & S & Monoclonal \\
72 & 7.5 & NR & S & Monoclonal \\
74 & 2.8 & NR & L & Monoclonal \\
76 & 23.8 & NR & L & Monoclonal \\
77 & 2.2 & NR & L & Monoclonal \\
Follicular carcinomas & & & \\
69 & 12.4 & NR & L & Monoclonal \\
71 & 42.2 & NR & S & Monoclonal \\
79 & 6.9 & NR & S & Monoclonal \\
80 & 41.2 & NR & L & Monoclonal \\
82 & 4.5 & NR & L & Monoclonal \\
85 & 40.2 & NR & L & Monoclonal \\
86 & 14.4 & NR & S & Monoclonal \\
87 & 2.33 & NR & S & Monoclonal \\
\hline
\end{tabular}

L, larger allele inactive; $S$, shorter allele inactive; NR, non-random $\mathrm{X}$-chromosome inactivation.
In order to evaluate the effect of contamination of tumour samples with non-neoplastic tissue, an additional experiment was performed by mixing DNA from a monoclonal tumour with different proportions of DNA from the corresponding polyclonal normal thyroid tissue. We observed that, for the samples containing more than $10 \%$ of normal thyroid tissue DNA, a non-random X-inactivation pattern was no longer detected (Fig. 2).

In the parallel analysis of tumour samples obtained from fresh and paraffin-embedded tissues, we observed that in five cases the ACR values were similar in both tissue samples, in one case the ACR value of fresh tissue was lower than the ACR value of the paraffin-embedded tissue and in the remaining seven cases the ACR values were higher for the fresh tissue samples.

Considering all cases of isolated PTC that were heterozygous for HUMARA polymorphism, in 19 (66\%) cases there was inactivation of the X-chromosome containing the larger allele against eight cases (28\%) in which the $\mathrm{X}$-chromosome containing the shorter allele was inactive. A similar trend was observed for FTA, where in $9 / 13(69 \%)$ cases there was inactivation of the $\mathrm{X}$-chromosome containing the larger allele, but not for FTC, where 6/11 (54\%) cases had the X-chromosome with the larger allele inactivated. In order to evaluate an hypothetical involvement of the CAG polymorphism in the development of these tumours, the length of the CAG alleles was determined in all cases of isolated PTC, FTA, FTC and in a population of 
41 healthy volunteers. In all of these subgroups the average number of $\mathrm{CAG}$ repeats for the larger allele was 23 , with S.D. ranging from 2.4 to 2.8 . The average

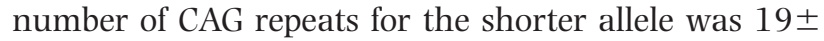
2.2 (mean \pm s.D.) for isolated PTC and 20 \pm 2.4 (mean \pm S.D.) for FTA, FTC and for healthy volunteers. Monoclonal PTC had the active X-chromosome alleles with an average number of CAG repeats of $20 \pm 2.7$ (mean \pm S.D.), while for monoclonal FTA and FTC the average number of repeats in the active allele was $21 \pm 2.3$ (mean \pm s.D.).

In 14 cases of PTC (13 isolated and one multinodular), clonality patterns of tumour-surrounding tissues were determined. Four of these samples were from cases where lyonization of the thyroid was observed, four samples showed monoclonal X-inactivation patterns with the same allele inactivated as the corresponding tumour, and for the remaining six samples (including the multinodular case of PTC) a polyclonal $\mathrm{X}$-inactivation pattern was found.

Three cases of multinodular PTC (cases 13, 16 and 60) showed evidence of multicentricity since the inactive alleles were different in the several tumour nodules (Fig. 3). In case 13, an undifferentiated tumour sample showed a pattern of random X-inactivation, which could be explained by the occurrence of demethylation associated with the dedifferentiation process (15). The remaining five cases of multinodular PTC were probably multifocal, since all tumour nodules showed non-random X-inactivation and had the same inactive chromosome (Table 3).

\section{Discussion}

Our results demonstrate that thyroid neoplasias of follicular origin are monoclonal, suggesting that these tumours arise from the aberrant growth of one single cell. The polyclonal result observed in two cases of PTC, in both fresh and paraffin-embedded samples, may be attributed to a significant contamination of
Table 3 Results of clonal analysis of multinodular PTC.

\begin{tabular}{|c|c|c|c|}
\hline Case & ACR values & $\begin{array}{c}\text { X-inactivation } \\
\text { pattern }\end{array}$ & $\begin{array}{c}\text { Inactive } \\
\text { allele }\end{array}$ \\
\hline \multirow[t]{4}{*}{13} & $\mathrm{~T}_{1}(\mathrm{RL})=5.9$ & NR & S \\
\hline & $\mathrm{T}_{2}(\mathrm{RL})=3.3$ & NR & $\mathrm{L}$ \\
\hline & $\mathrm{T}_{3}(\mathrm{LL})=5.5$ & NR & $\mathrm{L}$ \\
\hline & $\mathrm{T}_{4} \mathrm{PD}(\mathrm{LL})=1.5$ & $\mathrm{R}$ & - \\
\hline \multirow[t]{2}{*}{16} & $T_{1}(\mathrm{LL})=3.3$ & NR & L \\
\hline & $\mathrm{T}_{2}(\mathrm{RL})=3.4$ & NR & $\mathrm{S}$ \\
\hline \multirow{2}{*}{22} & $\mathrm{~T}_{1}(\mathrm{RL})=2.5$ & NR & $\mathrm{L}$ \\
\hline & $\mathrm{T}_{2}(\mathrm{LL})=2.5$ & NR & $\bar{L}$ \\
\hline \multirow[t]{2}{*}{23} & $\mathrm{~T}_{1}(\mathrm{RL})=2.0$ & NR & $\bar{S}$ \\
\hline & $\mathrm{T}_{2}(\mathrm{RL})=9.1$ & NR & $\mathrm{S}$ \\
\hline \multirow[t]{3}{*}{24} & $\mathrm{~T}_{1}(\mathrm{RL})=4.4$ & NR & $\mathrm{L}$ \\
\hline & $\mathrm{T}_{2}(\mathrm{LL})=2.2$ & NR & $\bar{L}$ \\
\hline & $\operatorname{Ad}(L L)=2.1$ & NR & $\mathrm{L}$ \\
\hline \multirow[t]{3}{*}{33} & $\mathrm{~T}_{1}(\mathrm{RL})=4.9$ & NR & $\mathrm{S}$ \\
\hline & $\mathrm{T}_{2}(\mathrm{LL})=5.8$ & NR & $\mathrm{S}$ \\
\hline & $\mathrm{ST}(\mathrm{RL})=1.3$ & $\mathrm{R}$ & - \\
\hline \multirow[t]{2}{*}{34} & $\mathrm{~T}_{1}(\mathrm{LL})=6.2$ & NR & $\mathrm{L}$ \\
\hline & $\mathrm{T}_{2}(\mathrm{RL})=6.0$ & NR & $\mathrm{L}$ \\
\hline \multirow[t]{3}{*}{60} & $T_{1}(R L)=14.0$ & NR & $\mathrm{S}$ \\
\hline & $\mathrm{T}_{2}(\mathrm{RL})=2.4$ & NR & $\mathrm{L}$ \\
\hline & $\mathrm{T}_{3}(\mathrm{RL})=2.3$ & NR & L \\
\hline
\end{tabular}

$\mathrm{T}_{n}$, samples from the different tumour nodules; $\mathrm{ST}$, tumour-surrounding tissue; Ad, Adenoma; PD, poorly differentiated; RL, right lobe; LL, left lobe; $\mathrm{NR}$, non-random X-inactivation; R, random X-inactivation; L, larger allele inactive; $\mathrm{S}$, shorter allele inactive.

these tumours with lymphocytes, since in both cases there was associated thyroiditis. Namba et al. (6) found that two out of three cases of PTC had a polyclonal pattern of X-inactivation, and considered this as the result of contamination by stromal cells, which are abundant in this type of tumours. A contamination with non-tumour polyclonal cells may also result from poor tissue dissection, leading to a wrongful assessment of clonality (Fig. 2). The contamination of tumour samples with normal thyroid tissue or lymphocytes can be, for the most part, avoided by carefully dissecting chosen areas from paraffin-embedded tissues where neoplasic cells predominate. However, our results show that, for most cases, the assessment of clonality

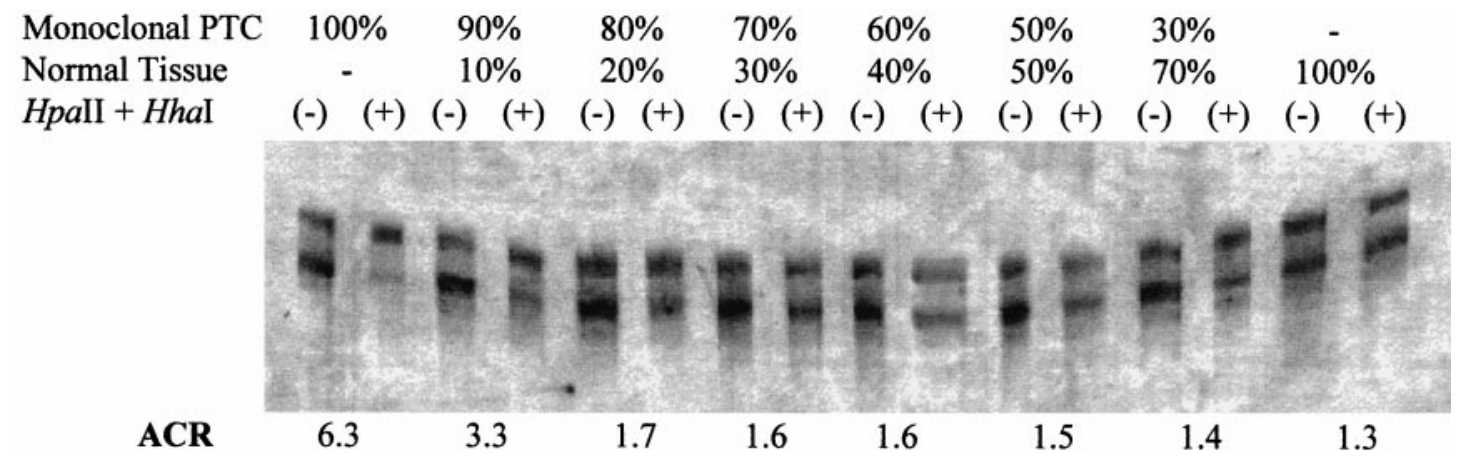

Figure 2 Study on the sensitivity of the PCR-HUMARA gene locus method for clonal analysis. DNA was extracted from a monoclonal PTC and from the corresponding polyclonal normal thyroid tissue. The two samples were mixed in proportions of 100:0, 90:10, 80:20, 70:30, 60:40, 50:50, 30:70 and 0:100. (-), Undigested DNA; (+), Hpall+Hhal digested DNA; ACR, allelic cleavage ratio (polyclonal if $<2$; monoclonal if $>2$ ). 


\section{Control Tumour 1 Normal Tumour 2}

$(-) \quad(+) \quad(-) \quad(+) \quad(-) \quad(+) \quad(-) \quad(+)$

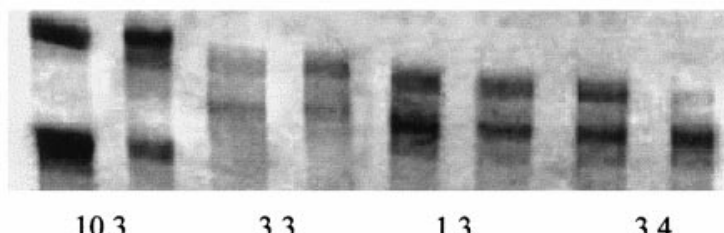

ACR

10.3

3.3

3.4
Figure 3 Multinodular PTC of multicentric origin (case 16, Table 3). Control - sample with monoclonal pattern; Tumour 1 - PTC nodule from the left lobe; Normal - normal thyroid tissue from the right lobe; Tumour 2 - PTC nodule from the right lobe; $(-)-$ undigested DNA; (+), Hpall+Hhal digested DNA.

by the HUMARA assay is best performed using DNA from fresh tissue, probably due to a better DNA quality (Table 1).

Insufficient DNA digestion could also contribute to an apparent polyclonal pattern of PTC in some studies. In most of these studies only the enzyme HpaII was used to distinguish the two differentially methylated X-chromosomes. However, some studies found that, at least in some tumour samples, the DNA methylation status might be altered and thus the use of HpaII alone may not produce a reliable result $(16,17)$. Li et al. (16) performed a second restriction, with HhaI, and found that, in some cases, a monoclonal pattern was only obtained after HhaI digestion. In the present study, an assay of digestion efficiency was performed, using each enzyme individually and the two simultaneously to digest a male DNA sample, which contains only one X-chromosome (Fig. 1). We found that the simultaneous use of HpaII and HhaI was the most efficient restriction condition, since we observed a complete disappearance of the band corresponding to the undigested fragment. Therefore, it is important to include appropriate controls in each digestion. The use of such controls has not been mentioned in most studies published so far.

In this study, we found evidence of lyonization of the thyroid in $20 \%$ of the cases. This phenomenon has been reported in normal lymphocytes in $23-33 \%$ of the cases $(7,18)$ and in $23 \%$ of the cases in a group of tissues which include thyroid, breast, uterus, skin, colon, kidney and bladder (19). The most accepted explanation for this phenomenon seems to be an early X-chromosome inactivation during embryogenesis (20).

Since PTCs are unencapsulated and poorly limited and hyperplasia is often formed in the vicinity, we assessed the clonality patterns of some cases of normal thyroid tissue surrounding these tumours. We found that $4 / 14(29 \%)$ samples could be assessed as having monoclonal X-inactivation patterns. The hypothesis of contamination of surrounding tissue with tumour tissue is unlikely, since we observed that only a contamination with up to $90 \%$ of monoclonal tumour tissue would produce a non-random X-inactivation pattern
(Fig. 2). Thus, this probably reflects the presence, in some cases, of a population of genetically altered cells in the tissues surrounding the tumour, even if their phenotypic features are normal upon histological analysis. Similarly, Khron et al. (14) found monoclonality in the tissues surrounding two toxic thyroid nodules.

In our study we found a greater incidence of isolated PTC $(66 \%)$ and FTA cases $(69 \%)$ with the larger HUMARA allele inactivated. This was not the case of FTC or of carcinomas of the breast (1) where both alleles were inactivated at similar proportions. Several studies have suggested a role for the length of CAG repeats in exon 1 of the androgen receptor gene in many androgen-regulated diseases (21). Giovannuci et al. (22) described an association between a reduced number of CAG repeats in exon 1 of the androgen receptor gene and an increased risk of prostate carcinoma. The molecular mechanism of this association may be an increase in the transactivation activity of the receptor for the cases in which the polymorphism has fewer CAG repeats (23). Shorter CAG repeats in exon 1 of the HUMARA gene have also been associated with more aggressive forms of breast cancer (24). Conversely, an expansion to 42-60 repeats (normal 11-35), leads to a reduction in the androgen receptor's transactivation activity and is associated with Kennedy's disease (X-linked spinal and bulbar muscular atrophy) (25).

Since our results could suggest an association between the length of CAG alleles and thyroid tumours, we determined the length of CAG alleles in the cases studied in order to test this hypothesis. However, we found no difference in the length of CAG alleles between PTC, FTA, FTC and the population of healthy volunteers. The higher number of cases of PTC and FTA with the larger HUMARA allele in the inactive X-chromosome was not due to a technical problem, since the corresponding normal tissue was polyclonal, and has probably occurred by chance.

One important aim of this study was to determine whether the cases of multiple PTC were due to metastasis from a single primary carcinoma (multifocality) or if they could correspond to tumours arising independently in a context of genetic and/or environmental predisposition (multicentricity). In three cases, we observed different alleles inactivated in each nodule, meaning that the model of independent origin was applicable. The remaining five conclusive cases had similar X-inactivation patterns for all nodules from each patient. This is more consistent with the hypothesis of multifocality. However, the possibility that the several nodules developed from different cells with the same inactivated X-chromosome can not be excluded. Our data are only in partial accordance with those obtained by Sugg et al. (26), who found that the rearrangements of the proto-oncogene RET occurring in multinodular PTC differ between the nodules. Although the authors attributed this finding to a multicentric origin for these tumours, it is possible that if 
these rearrangements do not constitute the primary mutational event, the different cell lines deriving from one tumour cell may follow different tumour progression pathways and, therefore, present different RET rearrangements. In line with this, thyroid tumours in cases of familial adenomatous polyposis show RET/ PTC oncogene activation, although the primary event is a germ-line mutation of the APC gene (27).

\section{Acknowledgements}

This work was supported by Ministério da Saúde (grant no. 145) and NRS Liga Portuguesa Contra o Cancro (Terry Fox) and POCTI/QCAIII, Portugal. ARM is a recipient of a $\mathrm{PhD}$ fellowship from FCT, Portugal (PRAXISXXI/BD/21329/99).

\section{References}

1 Noguchi S, Aihara T, Koyama H, Motomura K, Inaji H \& Imaoka S. Discrimination between multicentric and multifocal carcinomas of the breast trough clonal analysis. Cancer $1994 \mathbf{7 4} 872-877$.

2 Noguchi S, Aihara T, Koyama H, Motomura K, Inaji H \& Imaoka S. Differentiation of primary and secondary breast cancer with clonal analysis. Surgery 1994115 458-462.

3 Buller RE, Skilling JS, Sood AK, Plaxe S, Baergen RN \& Lager DJ. Field cancerization: why late recurrent ovarian cancer is not recurrent. American Journal of Obstetrics and Gynecology $1998 \mathbf{1 7 8}$ 641-649.

4 Harrer P, Broecker M, Zint A, Schatz H, Zumtobel V \& Derwahl M. Thyroid nodules in recurrent multinodular goiters are predominantly polyclonal. Journal of Endocrinological Investigation 1998 21 380-385.

5 Fialkow PJ. Clonal origin of human tumours. Biochimica et Biophysica Acta $1976 \mathbf{4 5 8} 283-321$.

6 Namba H, Matsuo K \& Fagin JA. Clonal composition of benign and malignant human thyroid tumours. Journal of Clinical Investigation 199086 120-125.

7 Fey MF, Peter HJ, Hinds HL, Zimmermann A, Liechti-Gallati S, Gerber $\mathrm{H}$ et al. Clonal analysis of human tumours with M27 $\beta$, a highly informative polymorphic X chromosome probe. Journal of Clinical Investigation $1992891438-1444$.

8 Kim H, Piao Z, Park C, Chung WY \& Park CS. Clinical significance of clonality in thyroid nodules. British Journal of Surgery $1998 \mathbf{8 5}$ $1125-1128$.

9 Ferraris AM, Mangerini R, Gaetani GF, Romei C, Pinchera A \& Pacini F. Polyclonal origin of medullary carcinoma of the thyroid in multiple endocrine neoplasia type 2. Human Genetics 199799 $202-205$.

10 Allen RC, Zoghbi HY, Moseley AB, Rosenblatt HM \& Belmont JW. Methylation of HpaII and HhaI sites near the polymorphic CAG repeat in the human androgen-receptor gene correlates with $\mathrm{X}$ chromosome inactivation. American Journal of Human Genetics $1992511229-1239$.

11 Thakker RV, Bouloux P, Wooding D, Chotai K, Broad TM, Spurr NK et al. Association of parathyroid tumours in multiple endocrine neoplasia type 1 with loss of alleles on chromosome 11. New England Journal of Medicine $1989321218-224$.

12 Green AJ, Sepp T \& Yates JR. Clonality of tuberous sclerosis haematomas shown by non-random X-chromosome inactivation. Human Genetics $199697240-243$.

13 Bassam BJ. Caetano-Anollés G \& Gresshoff PM. Fast and sensitive silver staining of DNA in polyacrylamide gels. Analytical Biochemistry $199119680-83$.

14 Krohn K, Fuhrer D, Holzapfel HP \& Paschke R. Clonal origin of toxic thyroid nodules with constitutively activating thyrotropin receptor mutations. Journal of Clinical Endocrinology and Metabolism 199883 130-134.

15 Grant SG \& Chapman VM. Mechanisms of X-chromosome regulation. Annual Review of Genetics 198822 199-233.

16 Li M, Cordon-Cardo C, Gerald WL \& Rosai J. Desmoid fibromatosis is a clonal process. Human Pathology 199627 939-943.

17 Diallo R, Schaefer KL, Poremba C, Shivazi N, Willmann V, Buerger $\mathrm{H}$ et al. Monoclonality in normal epithelium and in hyperplastic and neoplastic lesions of the breast. Journal of Pathology 2001 $19327-32$.

18 Gale RE, Wheadon H \& Linch DC. X-chromosome inactivation patterns using HPRT and PGK polymorphisms in haematologically normal and post-chemotherapy females. British Journal of Haematology 199179 193-197.

19 Mashal RD, Lester SC \& Sklar J. Clonal analysis by study of X chromosome inactivation in formalin-fixed paraffin-embedded tissue. Cancer Research 199353 4676-4679.

20 Belmont JW. Genetic control of X inactivation and processes leading to X-inactivation skewing. American Journal of Human Genetics 199658 1101-1108.

21 Yong EL, Lim J, Oi W, Ong V \& Mifsud A. Molecular basis of androgen receptor diseases. Annals of Medicine 200032 15-22.

22 Giovannuci E, Stampfer MJ, Krithivas K, Brown M, Brufsky A, Talcott J et al. The CAG repeat within the androgen receptor gene and its relationship to prostate cancer. PNAS $1997 \mathbf{9 4}$ 3320-3323.

23 Chamberlain NL, Driver ED \& Miesfield RL. The length and location of the CAG trinucleotide repeats in the androgen receptor $\mathrm{N}$-terminal domain affect transactivation function. Nucleic Acids Research 199422 3181-3186.

24 Yu H, Bharaj B, Vassilikos EJ, Giai M \& Diamandis EP. Shorter CAG repeat length in the androgen receptor gene is associated with more aggressive forms of breast cancer. Breast Cancer Research and Treatment 200059 153-161.

25 La Spada AR, Wilson EM, Lubahn DB, Harding AE \& Fischbeck $\mathrm{KH}$. Androgen receptor gene mutations in X-linked spinal and bulbar muscular atrophy. Nature 1991352 77-79.

26 Sugg SL, Ezzat S, Rosen IB, Freeman JL \& Asa SL. Distinct multiple RET/PTC gene rearrangements in multifocal papillary thyroid neoplasia. Journal of Clinical Endocrinology and Metabolism 1998 $834116-4122$.

27 Cetta F, Chiappetta G, Melillo RM, Petracci M, Montalto G, Santoro $\mathrm{M}$ et al. The ret/ptc1 oncogene is activated in familial adenomatous polyposis associated thyroid papillary carcinomas. Journal of Clinical Endocrinology and Metabolism 199883 1003-1006.

Received 14 March 2001

Accepted 18 September 2001 